\title{
Guinea-pig inclusion conjunctivitis as a model for the study of trachoma: clinical, microbiological, serological, and cytological studies of primary infection
}

\author{
MARJORIE A. MONNICKENDAM, S. DAROUGAR, \\ J. D. TREHARNE, AND ANGELA M. TILBURY
}

From the Virus Laboratory, Department of Clinical Ophthalmology, Institute of Ophthalmology, Judd Street, London WCIH 9QS

SUMMARY The course of primary ocular infection with guinea-pig inclusion conjunctivitis agent was followed in 2 groups of animals. One group of fully grown animals was repeatedly scraped; the other of small animals was used on 1 occasion only and scraped after clinical examination. The intensity of conjunctival inflammation was measured, conjunctival scrapings were taken, and the numbers of polymorphonuclear cells, mononuclear cells, and epithelial cells containing chlamydial inclusions were counted, and the level of antibodies in serum was measured. It was found that inflammation of the conjunctiva lasted for about 30 to 40 days, and the clinical features (oedema, hyperaemia, papillary reaction) were very similar in the 2 groups. Inclusions and polymorphonuclear cells were found for up to 21 days, and mononuclear cells were found on days 7 to 25 . Serum antibodies were first detected on day 10 and reached a peak on day 21 . The intensity of inflammation was significantly higher on day 2 in the animals which had been scraped. After this the severity of the inflammation and the course of disease were similar in the 2 groups.

Guinea-pig inclusion conjunctivitis (GPIC) is a naturally occurring disease of guinea-pigs, caused by a member of the species Chlamydia psittaci. ${ }^{2}$ Kazdan et $a .^{3}$ described the clinical features of naturally occurring and experimentally induced disease. Treharne ${ }^{4}$ measured the number of inclusions and inflammatory cells in conjunctival scrapings taken at various stages of the disease and the levels of antichlamydial antibodies in sera.

In this study we have looked at the clinical aspects of primary ocular infection, quantified the intensity of inflammation, and attempted to correlate this with the microbiological, cytological, and serological findings.

\section{Materials and methods}

ANIMALS

Female albino guinea-pigs of the Dunkin-Hartley strain were used. Those in the first experiment were fully grown animals weighing 600 to $700 \mathrm{~g}$,

Correspondence to Dr M. A. Monnickendam. those in the second experiment weighed 220 to $250 \mathrm{~g}$ at the start of the experiment.

\section{ORGANISMS AND INFECTION}

GPIC agent, strain A10, grown in the yolk sacs of embryonated hens' eggs, was used. Animals were infected by putting 1 drop of inoculum (containing $10^{6} \mathrm{EID}_{50}$ ) on to the conjunctiva.

\section{CLINICAL ASSESSMENT OF ACTIVE} INFLAMMATION

Animals were examined with a Zeiss Surgery Microscope II (Carl Zeiss, Jena). The upper and lower lids, bulbar conjunctiva, limbus, cornea, and palpebral conjunctivae were examined, and intensity of inflammatory changes was scored as mild (1), moderate (2), and severe (3). The maximum possible score per eye was 69 as shown in Table 1.

\section{CONJUNCTIVAL SCRAPINGS}

The left eye was anaesthetised with 1 drop of Novesine solution $(0.4 \%$ benoxinate hydrochloride and $0.01 \%$ chlorhexidine acetate). The eye was 
Table 1 Maximum scores of signs observed in guinea-pig inclusion conjunctivitis

\begin{tabular}{|c|c|c|}
\hline & & $\begin{array}{l}\text { Maximum } \\
\text { score }\end{array}$ \\
\hline Discharge & & 3 \\
\hline Lacrimation & & 3 \\
\hline Lid & $\begin{array}{cc}\text { Erythema (upper) } \\
\text { (lower) } \\
\text { Swelling } & \begin{array}{c}\text { (upper) } \\
\text { (lower) }\end{array}\end{array}$ & $\begin{array}{l}3 \\
3 \\
3 \\
3\end{array}$ \\
\hline Bulbar conjunctiva & $\begin{array}{l}\text { Hyperaemia } \\
\text { Chemosis }\end{array}$ & $\begin{array}{l}3 \\
3\end{array}$ \\
\hline Limbus & $\begin{array}{l}\text { Oedema } \\
\text { Follicles }\end{array}$ & $\begin{array}{l}3 \\
3\end{array}$ \\
\hline Cornea & Diffuse superficial keratitis & 3 \\
\hline Palpebral conjunctiva & $\begin{array}{cc}\text { Hyperaemia (upper) } \\
\text { Oedema } & \begin{array}{l}\text { (lower) } \\
\text { (upper) } \\
\text { (lower) } \\
\text { (upper) }\end{array} \\
\text { Papillae } & \begin{array}{l}\text { (lower) } \\
\text { (lower }\end{array} \\
\text { Follicles (size } \times \text { area) } & \text { (upper) } \\
,, \quad, \quad, \quad \text { (lower) }\end{array}$ & $\begin{array}{l}3 \\
3 \\
3 \\
3 \\
3 \\
3 \\
9 \\
9\end{array}$ \\
\hline Maximum total score & & 69 \\
\hline
\end{tabular}

blotted dry with a clean tissue and the upper and lower tarsal areas were scraped with an aluminium scraper. Scrapings were spread on slides, air dried, methanol fixed, and stained with Giemsa stain. Conjunctival scrapings were examined microscopically, at a magnification of $\times 400$, and the numbers of conjunctival epithelial cells, inclusion-bearing epithelial cells, polymorphonuclear cells, and mononuclear cells (lymphocytes, lymphoblasts, plasma cells, monocytes, and macrophages) in at least 5 nonadjacent microscope fields were counted. The results were expressed as the percentage of epithelial cells containing inclusions, and the number of mononuclear cells or polymorphonuclear cells per 100 epithelial cells. ${ }^{4}$

SERUM ANTIBODIES AGAINST GPIC AGENT Blood was collected by cardiac puncture and allowed to clot. The serum was separated by centrifugation and stored at $-20^{\circ} \mathrm{C}$. Total antichlamydial antibodies were measured by an indirect microimmunofluorescence test ${ }^{4}$ using antigen plaques of egg-grown GPIC agent and uninfected yolk-sac material as a control. Fluorescein isothiocyanatelabelled rabbit anti-guinea-pig whole globulin (GIBCO: Bio-Cult Ltd.) was used as a conjugate, with rhodamine-labelled bovine serum albumin (DIFCO) as a counterstain. The first dilution of serum was $1 / 8$, and only bright apple-green fluorescing particles were read as positive.
EXPERIMENTAL DESIGN

The first experiment was carried out on 5 fully grown animals, infected in the left eye, which was examined, photographed, and scraped immediately before infection and at intervals after infection. The second experiment was carried out on 40 young guinea-pigs. Fresh groups of 4 animals were taken immediately before infection and at various intervals after infection, eyes were examined, photographed, and scraped, and blood collected by cardiac puncture for serological testing.

STATISTICS

Student's $t$ test, modified for comparison of small samples, was used. ${ }^{5}$

\section{Results}

INCUBATION PERIOD

In both experiments the incubation period was less than 2 days.

\section{DURATION AND SEVERITY}

The duration of conjunctival inflammation was 21 to 40 days with a mean duration of 30 days. In the first experiment there was a large increase in the intensity of inflammation on day 2. This gradually decreased until day 7, increased for a further week, and then declined (Fig. 1a). In the second experiment the intensity of inflammation observed on day 2 was significantly lower than in the first experiment $(P<0.001)$. The responses seen from day 4 onward were very similar to those seen in the first group (Fig. 1a).

\section{SIGNS}

A mild to moderate lacrimation and discharge were present throughout the infection in both groups of animals. Erythema and swelling of the lids was observed on day 2 in all 5 animals in the first experiment and persisted in some animals until day 21 . In the second experiment these signs were not as common or as severe.

In the bulbar conjunctiva moderate to severe oedema was present from day 2 to day 21 in both groups of animals, and mild oedema was still present on day 35 in the second group (Fig. 2a). In the first experiment moderate hyperaemia was observed from day 2 to day 10 , and very mild hyperaemia was still present on day 25 . In the second experiment no hyperaemia was seen until day 4 , and mild hyperaemia persisted until day 35 (Fig. 2b).

In the palpebral conjunctivae the severity of hyperaemia, diffuse infiltration, and papillary hypertrophy was the same in upper and lower lids. The 
Figure la

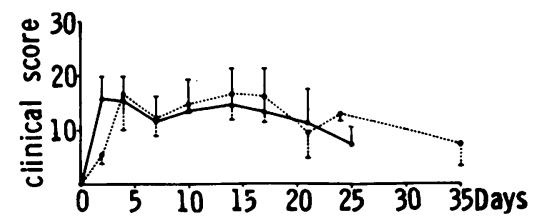

Figure $\mathrm{lb}$

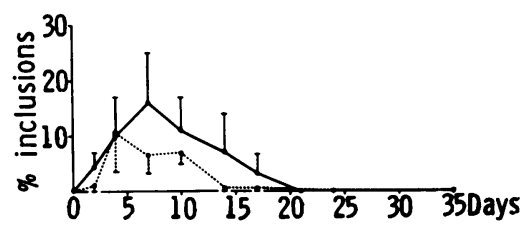

Figure lc

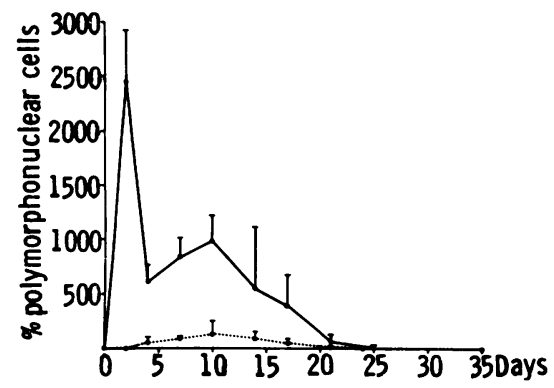

Figure ld

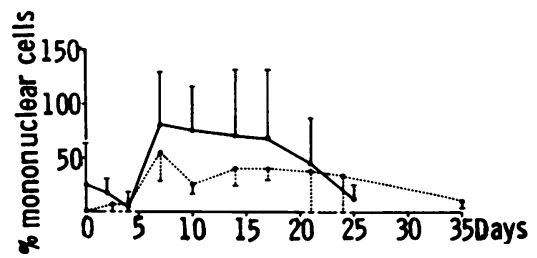

Figure le

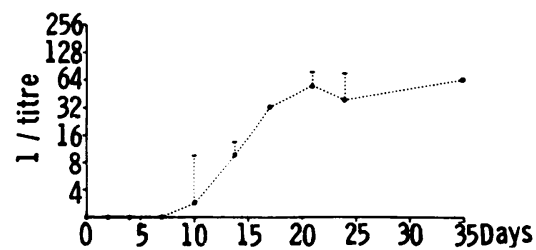

Fig. 1 The course of infection in 2 groups of animals (mean + standard deviation). Solid line = animals repeatedly scraped; dashed line = animals infected without scraping and used on 1 occasion only.

pattern of response was very similar in the 2 experiments. Moderate hyperaemia, diffuse infiltration, and papillary hypertrophy were first seen on day 2 , were most severe from day 7 to day 17 , and then declined (Figs. 2c, 2d, 2e). No follicles or conjunctival scars were found.

Corneal vessels, which are normally present, ${ }^{6}$ became congested during the acute phase of the infection, but no pannus (neovascularisation and cellular infiltration of the cornea) was observed. A mild, diffuse epithelial and subepithelial keratitis of the upper half of the cornea occurred sporadically.

\section{CHLAMYDIAL INCLUSIONS}

No inclusions were found in scrapings taken before infection. In the first experiment, in which animals were scraped immediately before infection, the percentages of epithelial cells containing inclusions increased on days 2 and 4, reaching a peak on day 7 (mean 16\%). The percentage then declined steadily, and no inclusions were seen on day 21 (Fig. 1b). In the second experiment, in which animals were not scraped before infection, the percentage of inclusions seen on day 2 was significantly lower than in the first experiment $(0.01>P>0.002)$. The highest level (mean 10.5\%) was seen on day 4 , and there was a decrease on day 7 , when the percentage of inclusions was again significantly lower than in the first experiment $(0.02>P>0.01)$. There was a

Figure 2b
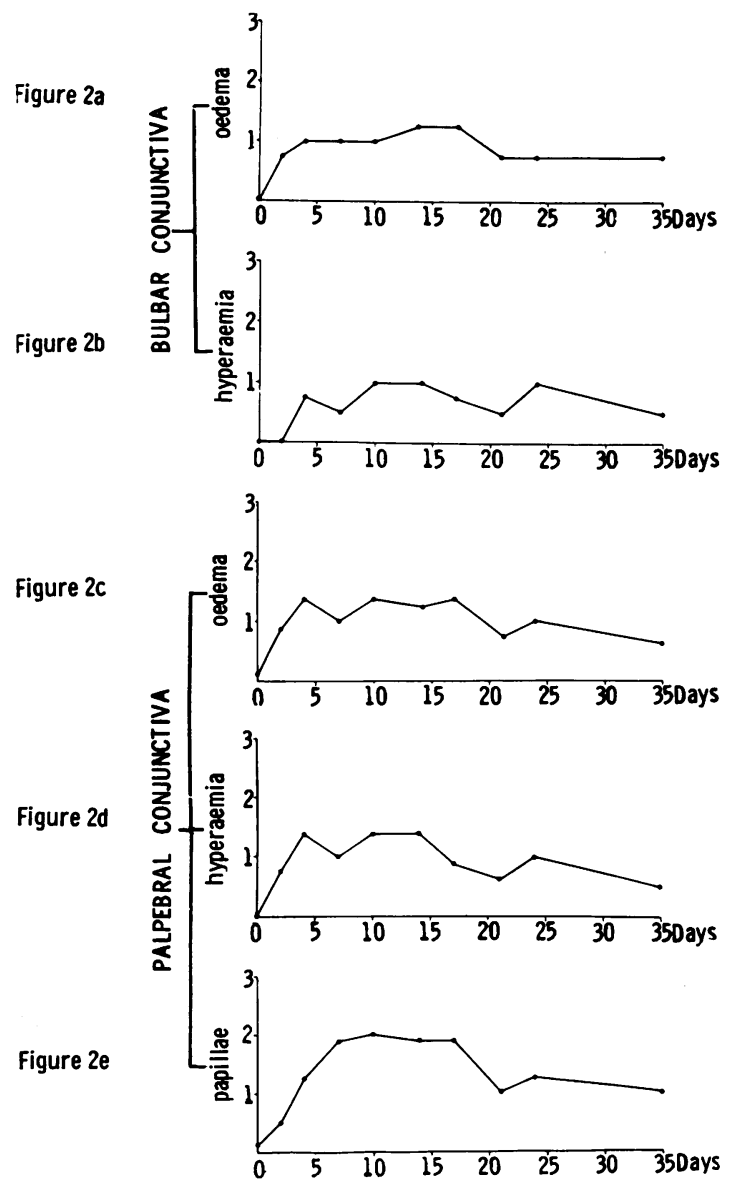

Fig. 2 Intensity and duration of signs in unscraped animals. 


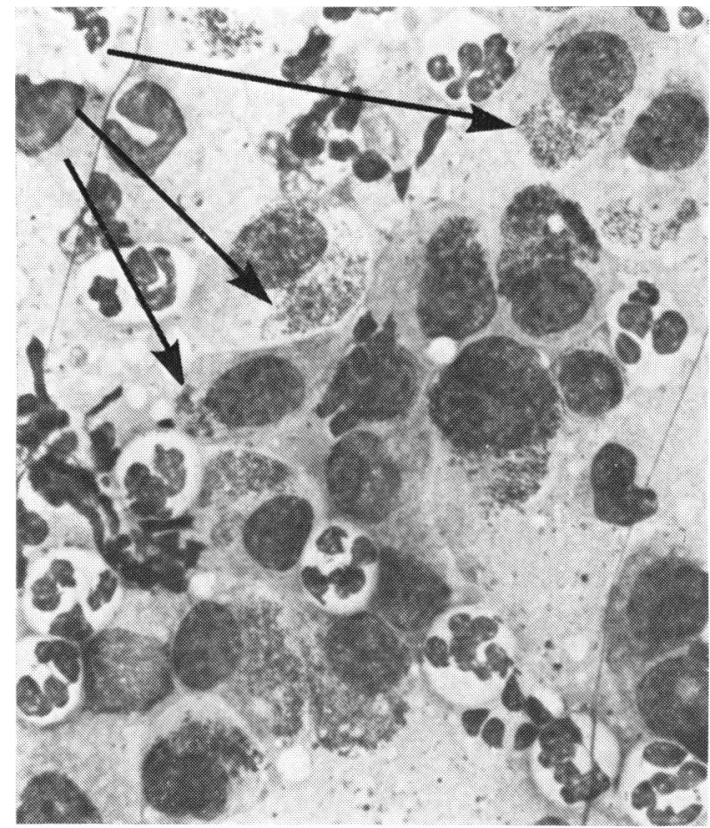

Fig. 3 Scraping taken 4 days after infection showing several inclusions in adjacent conjunctival epithelial cells (arrowed), many polymorphonuclear cells, and a few lymphocytes $(\times 670)$.

further decrease between days 10 and 14 , and no inclusions were seen after day 17 (Fig. 1b).

At the peak of infection, when a large number of cells were infected, inclusions were found in groups of adjacent epithelial cells (Fig. 3).

\section{POLYMORPHONUCLEAR CELLS}

Polymorphonuclear cells were rarely seen in scrapings from normal eyes. Those seen during infection consisted almost entirely of neutrophilic cells; eosinophils and basophils were very rarely seen. In the first experiment there was a massive increase in the level of polymorphonuclear cells following inoculation, with a mean peak value of $2450 \%$ on day 2 , followed by a large reduction on day 4 (Fig. 1c). There was a second peak on day 10 (mean level $980 \%$ ), after which the number of cells steadily declined, returning to normal levels by day 25 . In the second experiment there was a much smaller increase in neutrophils, with a mean peak level of $130 \%$ on day 10 , followed by a gradual decrease, returning to normal levels on day 21 (Fig. 1c).

\section{MONONUCLEAR CELLS}

A few mononuclear cells were seen before infection in the animals used in the first experiment. In both experiments the number of mononuclear cells increased significantly between days 4 and $7(0.02>$ $P>0.01$ ), to reach mean peak levels of $80 \%$ and $55 \%$ respectively (Fig. 1d). Lymphocytes predominated, though some lymphoblasts, plasma cells, macrophages, and monocytes were also seen. In the first experiment the number of cells remained high $(45 \%$ to $75 \%)$ until day 21 , and returned to preinfection levels by day 25 . In the second experiment relatively high numbers were seen on days 10 to $24(25 \%$ to $40 \%)$; at day 35 the mean level was $10 \%$.

\section{SERUM ANTIBODIES}

Total serum antibodies against GPIC agent were measured in the animals used in the second experiment. No antibodies were present on day 0 , and none were detected until day 10 , when 2 out of 4 animals were positive at the first dilution (1/8). On day 14 all 4 sera contained antibodies, and there were further increases on day 17 and 21 . On day 35 all 4 animals had levels of 1 in 64 (Fig. 1e).

\section{Discussion}

There are 2 features of the normal guinea-pig eye which have led to some confusion when clinical signs in guinea-pig eyes have been compared with signs in man. Firstly, the normal guinea-pig eye has superficial corneal vessels which extend from the limbus toward the centre of the cornea; these can be seen with the aid of an operating microscope or slit-lamp. When the eye is infected, these vessels dilate and are more easily seen, but should not be mistaken for pannus. Secondly, there are masses of lymphoid tissue in the upper and lower palpebral conjunctivae of the normal guinea-pig, which are also found in the fetal guinea-pig, ${ }^{6}$ and they should not therefore be mistaken for the follicles which develop on the conjunctivae in trachoma. In the experiments described here we observed what appeared to be follicles, which on histological examination proved to be the normal folds of the conjunctiva, swollen during infection (unpublished results).

The clinical signs and the course of the disease were very similar in the 2 groups of animals. It is evident that changes in the intensity of inflammation were not directly related to changes in the numbers of inclusions, polymorphonuclear cells, or mononuclear cells alone. Different patterns of cellular reaction were seen at different stages of the disease. The percentage of epithelial cells containing inclusions reached a peak early in the disease (days 4 to 7 ) and then decreased; none were seen after about day 20. Increased levels of polymorphonuclear cells were found only when inclusions were also present. 
The mononuclear cells had a different pattern of behaviour from polymorphonuclear cells and inclusions; few were seen until day 7 , when a sharp increase occurred. High levels were maintained until about day 20. It is interesting to note that after the increase in mononuclear cells on day 7 the percentage of epithelial cells containing inclusions decreased, and the high level of mononuclear cells was maintained until no more inclusions were found. Antichlamydial antibodies were not consistently found until day 14 , when the number of inclusions had already decreased. These results are similar to those of Treharne, ${ }^{4}$ who found the highest percentage of epithelial cells containing inclusions on days 4 to 8 , whereas antibody titres of $1 / 8$ or more were not found in all animals until day 15 .

The role of trauma on primary ocular infection was examined by comparing the 2 experiments, one using animals which were scraped repeatedly, the other using animals which were not scraped. The levels of inflammation were very similar in the 2 groups of animals except on day 2, when the levels of inflammation, polymorphonuclear cells, and inclusion-containing epithelial cells were significantly higher in the scraped group. Although the levels of inflammation after day 2 were very similar in the 2 groups, the level of inclusions was generally higher in the scraped group of animals, and this was associated with higher levels of inflammatory cells, particularly polymorphonuclear cells. We therefore conclude that the major effect of scraping is on the very early stages of infection. When adult human volunteers were inoculated with strains of
C. trachomatis isolated from 2 babies with ophthalmia neonatorum, Jawetz et al. ${ }^{7}$ found that scraping had no effect on the susceptibility of the conjunctiva to infection or the course of the disease.

In the following paper ${ }^{8}$ we describe the effects of reinfection with GPIC agent, which produces chronic disease and lesions similar to those of trachoma.

We thank Professors Barrie Jones and John Turk for helpful discussions, and the Medical Research Council and an anonymous donor for financial support.

\section{References}

${ }^{1}$ Murray ES. Guinea-pig inclusion conjunctivitis virus. I. Isolation and identification as a member of the psittacosislymphogranuloma-trachoma group. J Infect Dis 1964; 114: 1-12.

${ }^{2}$ Gordon FB, Weiss E, Quan AL, Dressler HR. Observations on guinea-pig inclusion conjunctivitis agent. $J$ Infect Dis 1966; 116: 203-207.

${ }^{\mathbf{3} K a z d a n} \mathbf{J J}$, Schachter J, Okumoto M. Inclusion conjunctivitis in the guinea-pig. Am J Ophthalmol 1967; 64: 116-124.

tTreharne JD. In: Nichols RL, ed. Trachoma and Related Disorders Caused by Chlamydial agents. International Congress Series No. 223. Amsterdam, London, Princeton: Excerpta Medica 1971; 435-444.

${ }^{5}$ Bailey NTJ. Statistical Methods in Biology. London: English Universities Press, 1959.

${ }^{6}$ Dwyer R St C. Local immune reactions in the guinea-pig outer eye. Ph.D. thesis. University of London, 1978.

'Jawetz B, Rose L, Hanna L, Thygeson P. Experimental inclusion conjunctivitis in man. Measurements of infectivity and resistance. JAMA 1965; 194: 620-632.

${ }^{8}$ Monnickendam MA, Darougar S, Treharne JD, Tilbury AM. Development of chronic conjunctivitis with scarring and pannus, resembling trachoma, in guinea-pigs. $B r J$ Ophthalmol 1980; 64: 284-290. 